\author{
Malgorzata Korzycka-Iwanow ${ }^{1}$, Pawee Wojciechowski ${ }^{2}$
}

\title{
Żywność ekologiczna w prawie USA i Unii Europejskiej
}

\section{Wstęp}

Żywność stanowi szczególnego rodzaju produkt, który jest niezbędny dla egzystencji człowieka. Od wielu lat regulacje prawne dotyczące wytwarzania i obrotu żywności w wielu państwach świata, w tym w USA oraz w UE, nakierowane są na zapewnienie bezpieczeństwa żywności. Każdy produkt żywnościowy znajdujący się na rynku musi być bezpieczny, a podstawowym czynnikiem umożliwiającym konkurencję na rynku żywności jest jej jakość. W związku z tym, zarówno w Unii Europejskiej, jak też wielu państwach na całym świecie intensywnie rozwijana jest polityka jakości produktów rolnych i żywności. Jednym z systemów jakości pozwalających na wyróżnienie produktu rolnego i żywności jest produkcja ekologiczna (obok m.in. produktów regionalnych i tradycyjnych). Rosnący popyt na produkty ekologiczne powoduje rozwój rynku żywności ekologicznej, odnotowywany przede wszystkim w krajach wysoko rozwiniętych, głównie w Stanach Zjednoczonych i Unii Europejskiej. ${ }^{3}$ Warto dodać, że produkcja ekologiczna stanowi odpowiedź na zwiększający się popyt na produkty rolne wytwarzane $\mathrm{z}$ wykorzystaniem metod naturalnych, ale stanowi ona także jedną z metod poprawy stanu środowiska. W krajach UE, pomimo stosowania wsparcia finansowego dla rolnictwa ekologicznego, podaż nie pokrywa zapotrzebowania, dlatego żywność ekologiczna jest importowana spoza Unii (zboże, mięso, mleko i jego przetwory, warzywa, owoce, soki oraz produkty tropikalne). ${ }^{4}$ Żywność ekologiczna importowana $\mathrm{z}$ państw trzecich powinna spełniać takie same wymagania, jak żywność wytworzona w UE, a w regulacji prawnej dotyczącej produkcji ekologicznej przewidziane zostały mechanizmy uznawania produktów ekologicznych wytworzonych w państwach trzecich. Produkcja żywności ekologicznej bardzo intensywnie rozwija się w USA. W 2012 r. za-

Uniwersytet Warszawski.

Uniwersytet Warszawski.

Zob. D. Komorowska, Ekonomika produkcji ekologicznej w Polsce, „Zeszyty Naukowe Szkoły Głównej Gospodarstwa Wiejskiego: Ekonomika i Organizacja Gospodarki Żywnościowej” 2009, nr 73, s. 143.

Ibidem, s. 143. 
warte zostało porozumienie pomiędzy USA i UE dotyczące wzajemnego uznawania żywności ekologicznej.

Celem niniejszego opracowania jest ustalenie znaczenia pojęcia ,żywność ekologiczna" w prawie unijnym i prawie amerykańskim, a także analiza wzajemnych relacji tych pojęć w kontekście funkcjonowania mechanizmów wzajemnego uznawania produktów ekologicznych.

\section{Rolnictwo ekologiczne - podstawy prawne}

Sama idea rolnictwa ekologicznego, zwanego też „naturalnym” lub „,rolnictwem bez chemii" wywodzi się od wypracowanej już w latach dwudziestych XX w., tzw. metody gospodarowania biodynamicznego (biologisch-dynamische Wirtschaftsweise), autorstwa austriackiego filozofa i przyrodnika Rudolfa Steinera, twórcy systemu filozoficzno-religijnego zwanego antropozofią. ${ }^{5} \mathrm{~W}$ latach 30 . i 40 . XX w. w Szwajcarii i Niemczech opracowana została przez H. Mullera, H.P. Ruscha kolejna metoda produkcji ekologicznej, organiczno-biologiczna (organisch-biologischer Landbau.${ }^{6}$ Metoda ta polega na uzyskiwaniu optymalnych plonów o wysokiej jakości, bez stosowania nawozów mineralnych i pestycydów, przy zwracaniu szczególnej uwagi na następstwo roślin w płodozmianie i stosowanie nawozów zielonych, w tym poplonów osłaniających glebę zimą oraz utrzymanie żyzności gleby, w warunkach maksymalnie zamkniętego obiegu materii. Podstawy agrotechniczne tej metody (najstaranniej opracowane w porównaniu z innymi kierunkami produkcji rolniczej ,w zgodzie z przyrodą") stały się podstawą agrotechniki w rolnictwie ekologicznym. W latach 40. XX w. w Wielkiej Brytanii rozwijana była koncepcja rolnictwa organicznego (organic agriculture), opartego na założeniu, iż gospodarstwo stanowi organicznie zrównoważoną całość. W latach 60. XX w. we Francji rozwijano ideę rolnictwa biologicznego.?

W Unii Europejskiej idea rolnictwa ekologicznego zaczęła być rozwijana w połowie lat siedemdziesiątych XX w., w ramach polityki ekologicznej, gdzie rolnictwo $\mathrm{z}$ jednej strony traktowane było jako źródło powstania zanieczyszczeń, a z drugiej

Interpretacja przyrody, wynikająca z antropozofii, podkreśla ścisłą współzależność ziemi, człowieka i kosmosu oraz zakłada, że za pomocą określonych preparatów i działań człowiek może aktywizować różne formy energii obecne w przyrodzie (występują tu pewne analogie do filozoficznego pojęcia vis vitalis, czyli siły życia). Zob. D. Stankiewicz, Rolnictwo ekologiczne, Informacja nr 673, Biuro Studiów i Ekspertyz, 1999 r, dostępne na: http:// biurose.sejm.gov.pl/teksty/i-673.htm; M. Zuba, Szanse i bariery w integracji łańcucha żywności ekologicznej w Polsce, „Zeszyty Naukowe Wyższej Szkoły Ekonomii i Informatyki” seria Ekonomia 2012, z. 3, s. 263.

Zob. D. Stankiewicz, Rolnictwo ekologiczne..., op. cit.; M. Zuba, Szanse i bariery w integracji łańcucha żywności ekologicznej..., op. cit., s. 263, P. Wojciechowski, Gospodarstwo rodzinne jako gospodarstwo ekologiczne w prawie polskim i prawie UE, [w:] Prawne mechanizmy wspierania i ochrony rolnictwa rodzinnego w Polsce i innych państwach Unii Europejskiej, P. Litwiniuk (red.), Warszawa 2015, s.126. ki, A. Zieliński (red.), Kluczbork 2002, s. 35, P. Wojciechowski, Gospodarstwo rodzinne jako gospodarstwo ekologiczne..., op. cit., s. 127. 
strony jako sposób przeciwdziałania niekorzystnym tendencjom. ${ }^{8} \mathrm{~W}$ Europie Zachodniej od lat $60 . \mathrm{XX}$ w. wzrastało też zainteresowanie konsumentów produktami ekologicznymi. ${ }^{9}$ Zarówno wzrost popytu na produkty ekologiczne, jak też potrzeba ochrony środowiska naturalnego, przyczyniły się do wydania na szczeblu wspólnotowym na początku lat 90 . zeszłego stulecia pierwszej regulacji prawnej dotyczącej bezpośrednio rolnictwa ekologicznego, tj. rozporządzenia nr 2092/91 w sprawie rolnictwa ekologicznego oraz oznakowania jego produktów i środków spożywczych. ${ }^{10}$ Rozporządzenie to zostało uchylone rozporządzeniem Rady nr 834/2007 z dnia 28 czerwca 2007 r. w sprawie produkcji ekologicznej i znakowania produktów ekologicznych $(\ldots.){ }^{11}$

Przesłanki wydania unijnej regulacji dotyczącej ekologicznych metod produkcji, a w konsekwencji i cele tej regulacji są dwojakiego rodzaju. $\mathrm{Z}$ jednej strony, zwiększał się popyt konsumentów na produkty ekologiczne, przez co powstał nowy rynek dla produktów rolnych, o cenach wyższych niż dla produktów konwencjonalnych, co wymagało wprowadzenia przepisów, których celem jest przede wszystkim ochrona interesów ekonomicznych konsumentów oraz rzetelność obrotu tymi produktami. ${ }^{12} \mathrm{Z}$ drugiej strony podkreślano korzystność wykorzystywania ekologicznych metod produkcji dla środowiska, dobrostanu zwierząt i zrównoważonego rozwoju obszarów wiejskich, a zatem celem regulacji stała się także ochrona środowiska. ${ }^{13}$ Ekologiczne metody produkcji sprzyjają bowiem utrzymaniu żyzności gleby i ochronie środowiska przed skażeniami i zanieczyszczeniami pochodzenia rolniczego, przyczyniają się do ochrony wód gruntowych i zachowania naturalnego krajobrazu i pozwalają zachować równowagę biologiczną w środowisku przyrodniczym. ${ }^{14}$ Powoduje to, iż w pełni uzasadnione jest wyodrębnienie dwóch nurtów ustawodawstwa, a w konsekwencji dwóch bloków przepisów dotyczących rolnictwa ekologicznego. W pierwszym z nich (nurt główny) przedmiotem regulacji są wszystkie etapy produkcji i dystrybucji produktów rolnictwa ekologicznego oraz ich kontrola (regulacja produktu ekologicznego). W drugim nurcie (nurt uzupełniający), rolnictwo ekologiczne jest traktowane jako element szerszej regulacji nastawionej na realizację celów związanych z ochroną środowiska. ${ }^{15}$ Ten drugi nurt w sposób

Zob. M.A. Król, Koncepcja rolnictwa ekologicznego..., op. cit., s. 36.

Zob. P. Wojciechowski, Gospodarstwo rodzinne jako gospodarstwo ekologiczne..., op. cit., s. 127.

Rozporządzenie Rady (EWG) nr 2092/91 z dnia 24 czerwca 1991 r. w sprawie produkcji ekologicznej produktów rolnych oraz znakowania produktów rolnych i środków spożywczych (Dz.Urz. WE L 198 z dnia 22 lipca 1991 r., s. 1).

Rozporządzenie Rady (WE) nr 834/2007 z dnia 28 czerwca 2007 r. w sprawie produkcji ekologicznej i znakowania produktów ekologicznych i uchylające rozporządzenie (EWG) nr 2092/91 (Dz.Urz. UE L 189 z dnia 20 lipca 2007 r., s. 1 ze zm.).

Zob. akapit 1-4 preambuły do rozporządzenia 2092/91 oraz pkt 1 i 3 preambuły do rozporzadzenia 834/2007. Zob. akapit 2 preambuły do rozporządzenia 2092/91 oraz pkt 1 i 12-16 preambuły do rozporządzenia 834/2007, a także PROW 2014-2020, s. 26.

Zob. D. Komorowska, Ekonomika produkcji ekologicznej w Polsce..., op. cit., s. 143.

Zob. S. Prutis, Regulacje prawne produkcji ekologicznej w rolnictwie polskim, „Studia luridica Agraria” 2013, t. XI, s. 42. 
istotny uwidacznia się w regulacjach dotyczących wsparcia produkcji ekologicznej ze środków funduszy unijnych. ${ }^{16}$

Zainteresowanie rolnictwem ekologicznym z Europy przeniosło się do USA. Sformułowanie „ekologiczna” (organic) w odniesieniu do metody produkcji, w której rolnik dążył do poprawy stanu gleby poprzez stosowanie naturalnych nawozów (obornika i kompostu) oraz unikanie syntetycznych substancji chemicznych po raz pierwszy użyte zostało w USA w 1942 r., a już w końcu lat 40. ubiegłego wieku prowadzona była ekologiczna działalność rolnicza. ${ }^{17}$ Początkowo była to produkcja prowadzona w niewielkich gospodarstwach dla zaspokojenia głównie własnych potrzeb, jednak w okresie 50 lat gospodarstwa ekologiczne mocno rozwinęły się. Opinia publiczna zaczęła zwracać uwagę na potencjalnie negatywny wpływ na środowisko i zdrowie publiczne środków chemicznych wykorzystywanych w rolnictwie. Zaczęto też prowadzić badania nad niechemicznymi i nieintensywnymi metodami produkcyjnymi. Stopniowo zaczęła się zwiększać liczba rolników wdrażających $\mathrm{w}$ swoich gospodarstwach ekologiczne metody produkcji. ${ }^{18} \mathrm{~W}$ poszczególnych stanach zaczęto wprowadzać regulacje stanowe dotyczące produkcji ekologicznej (pierwsza regulacja stanowa wprowadzona została w 1973 r. w stanie Oregon, a pod koniec lat 80. regulacja produkcji ekologicznej wprowadzona była w $22 \operatorname{stanach}^{19}$ ). Standardy przyjmowane były też przez poszczególne organizacje zrzeszające producentów i przetwórców. Powodowało to dezorientację konsumentów oraz brak zaufania do żywności ekologicznej. ${ }^{20}$ Nie były też podejmowane żadne działania publiczne mające na celu wsparcie produkcji ekologicznej. ${ }^{21}$ Podmioty wytwarzające tego rodzaju żywność były zatem zainteresowane wydaniem ustawy dotyczącej produkcji ekologicznej. Doprowadziło to do wydania regulacji prawnej dotyczącej produkcji ekologicznej na szczeblu federalnym w 1990 r. Do ustawy rolniczej (Farm Bill) wprowadzony został nowy tytuł (tytuł XXI) Ustawą o produkcji ekologicznej żywności (The Organic Foods Production Act of 1990 - OFPA ${ }^{22}$ ). Ustawa ta stanowi podstawę prawną dla rozwoju ogólnokrajowych norm dotyczących wytwarzania i obrotu żywności ekologicznej w celu ochrony interesów konsumentów i przedsiębiorców działających na rynku produktów ekologicznych. W ustawie tej Sekretarz

Zob. pkt 23 Preambuły do rozporządzenia nr 1305/2013 z dnia 17 grudnia 2013 r. w sprawie wsparcia rozwoju obszarów wiejskich przez Europejski Fundusz Rolny na rzecz Rozwoju Obszarów Wiejskich (EFRROW) (Dz. Urz. UE L 347 z dnia 20 grudnia 2013 r., s. 487).

17 Zob. V.J. Watnick, The Organic Foods Production Act, the Process/Product Distinction, and a Case for More End Product Regulation in the Organic Foods Market, „UCLA Journal of Environmental Law and Policy” 2014, 32(1), s. 45. C.S. Carroll, What Does "Organic" Mean Now? Chickens and Wild Fish are Undermining the Organic Food Production Act of 1990, „San Joaquin Agricultural Law Review” 2004, 117, s. 118. Zob. R. Johnson, CRS Report for Congres, Organic Agriculture in the United States: Program and Policy Issues, Congressional Reserch Service, 2008, s. 1. Zob. V.J. Watnick, The Organic Foods Production Act..., op. cit., s. 45.

Zob. K.C. Amaditz, The Organic Foods Production Act of 1990 and Its Impending Regulations: A Big Zero for Organic Food?, „Food and Drug Law Journal” 1997, s. 539, R. Johnson, CRS Report for Congres, Organic Agriculture in..., op. cit., s. 3.

Zob. R. Johnson, CRS Report for Congres, Organic Agriculture in..., op. cit., s. 1. Organic Foods Production Act of 1990 (7 U.S.C. 6501 et seq.), dalej jako OFPA. 
do spraw rolnictwa (U.S. Department of Agriculture - USDA) zobowiązany został m.in. do ustanowienia Narodowego Programu Produkcji Ekologicznej (National Organic Production Program ${ }^{23}$ ), który obejmuje ramy prawne dla produkcji ekologicznej, za realizację których odpowiedzialna jest jednostka organizacyjna pod nazwą Agricultural Marketing Service wyodrębniona w ramach U.S. Department of Agriculture) oraz został on upoważniony do powołania Narodowej Rady Standardów Ekologicznych (National Organic Standards Board - NOSB). W 1992 r. wyznaczeni zostali pierwsi członkowie Narodowej Rady Standardów Ekologicznych, a w 2000 r. w dzienniku urzędowym (Federal Register) opublikowane zostały zasady ustanawiające Narodowy Program Ekologiczny ${ }^{24}$ (w tytule 7 „rolnictwo”, części 205, Kodeksu Federalnych Regulacji (The Code of Federal Regulations ${ }^{25}$ ).

Przesłanki wydania regulacji dotyczących produkcji metodami ekologicznymi w USA były odmienne niż w UE, poza tym inny jest też cel tej regulacji. Impulsem dla wydania regulacji na szczeblu federalnym było wprowadzenie przez niektóre ze stanów regulacji wewnątrzstanowych oraz ustanowienie wielu prywatnych standardów dla żywności ekologicznej, co z jednej strony powodowało trudności w swobodnym obrocie produktami ekologicznymi, a z drugiej strony, ze względu na brak jednolitego standardu, skutkowało tym, że ze względu na wielość standardów i sposobów znakowania, konsumenci mieli ogromne trudności z odróżnieniem żywności wytworzonej metodami ekologicznymi od żywności konwencjonalnej. W konsekwencji za kluczowe cele regulacji produkcji ekologicznej uznano ochronę interesów konsumentów poprzez zapewnienie jednolitego standardu produktów oraz ułatwienia handlu międzystanowego żywności wyprodukowanej metodami ekologicznymi. $^{26}$

\section{3. Żywność ekologiczna w prawie unijnym}

Zarówno w poprzednio obowiązującym w Unii Europejskiej rozporządzeniu 2092/91, jak też w zastępującym go od dnia 1 stycznia 2009 r. rozporządzeniu nr 834/2007 określone zostały cele, zasady i wymagania dotyczące produkcji ekologicznej, zasady znakowania żywności ekologicznej, a także wprowadzono uregulowania dotyczące systemu kontroli. W rozporządzeniu tym zdefiniowano wiele pojęć, jednak nie uwzględniono definicji pojęcia ,żywność ekologiczna”. Znaczenie tego pojęcia może być jednak ustalone z wykorzystaniem dwóch innych definicji,

24 Dostępny na: https://www.federalregister.gov/articles/2000/12/21/00-32257/national-organic-program oraz na: http://www.ams.usda.gov/AMSv1.0/nop. Warto zaznaczyć, że pierwszy projekt tych zasad przedłożony został przez AMS w 1997 r., jednak w konsultacjach społecznych zgłoszono ponad 28 tys. uwag. "prawem administracyjnym") publikowanych w Rejestrze Federalnym (Federal Register) przez urzędy centralne USA. Jest podzielony na 50 tytułów. Tytuł 7 ,rolnictwo” podzielony jest na 42 rozdziały, w tym rozdział I obejmujący podrozdział „M” stanowiący NOP. Zob. § 2102 OFPA. 
tj. definicji pojęć: „ekologiczny” oraz „produkcja ekologiczna”. Zgodnie z rozporządzeniem nr 834/2007 „ekologiczny” oznacza pochodzący z produkcji ekologicznej lub z nią związany, ${ }^{27} \mathrm{z}$ kolei ,produkcja ekologiczna” oznacza stosowanie metody produkcji zgodnej z zasadami określonymi w rozporządzeniu nr 834/2007 na wszystkich etapach produkcji, przygotowania i dystrybucji. ${ }^{28}$ Do podstawowych zasad produkcji ekologicznej uregulowanych w rozporządzeniu nr 834/2007 oraz rozporządzeniach wykonawczych do niego ${ }^{29}$ należy oparcie produkcji na systemach ekologicznych wykorzystujących wewnątrzsystemowe zasoby naturalne, ograniczenie stosowania środków zewnętrznych oraz ścisłe ograniczenie stosowania środków z syntezy chemicznej. ${ }^{30} \mathrm{~W}$ odniesieniu do rolnictwa wymienionych zostało dodatkowo kilkanaście zasad, w tym m.in. recykling odpadów i produktów ubocznych pochodzenia roślinnego i zwierzęcego jako środek do produkcji roślinnej i zwierzęcej; utrzymywanie zdrowotności roślin poprzez stosowanie środków zapobiegawczych, takich jak dobór odpowiednich gatunków i odmian odpornych na szkodniki i choroby, odpowiedni płodozmian, metody mechaniczne i fizyczne oraz ochrona naturalnych wrogów szkodników; utrzymywanie zdrowia zwierząt poprzez wspomaganie naturalnej obrony immunologicznej zwierząt, dobór odpowiednich ras hodowlanych oraz praktyki gospodarskie; a także utrzymywanie różnorodności biologicznej naturalnych ekosystemów wodnych, zdrowia środowiska wodnego oraz jakości otaczających ekosystemów wodnych i lądowych w produkcji akwakultury. ${ }^{31}$ Przy produkcji ekologicznej niedopuszczalne jest wykorzystywanie GMO i produktów wytworzonych z GMO lub przy ich użyciu, ${ }^{32}$ a ponadto zakazane jest poddawanie produktów ekologicznych działaniu promieniowania jonizującego ${ }^{33}$ Poza tym, w rozporządzeniu $\mathrm{nr}$ 834/2007 uregulowano też szereg szczegółowych wymagań mających zastosowanie do produkcji roślinnej oraz produkcji zwierzęcej. ${ }^{34}$

Zgodnie z regulacją unijną określenie „ekologiczny” i jego pochodne jak „eko”, „bio" lub inne określenia sugerujące wytworzenie zgodnie z ekologicznymi metodami produkcji mogą być stosowane przy nieprzetworzonych produktach rolnych wyłącznie wtedy, gdy wszystkie składniki tego produktu zostały wyprodukowane zgodnie z wymogami określonymi w rozporządzeniu nr 834/2007. ${ }^{35}$ Przy produktach przetworzonych tego rodzaju określenia mogą być stosowane w głównym polu

Zob. art. 2 c) rozporządzenia 834/2007.

Zob. art. 2 a rozporządzenia 834/2007.

Zob. rozporządzenie Komisji (WE) nr 889/2008 z dnia 5 września 2008 r. ustanawiające szczegółowe zasady wdrażania rozporządzenia Rady (WE) nr 834/2007 (...) oraz Rozporządzenie Komisji (WE) nr 1235/2008 z dnia 8 grudnia 2008 r. ustanawiające szczegółowe zasady wykonania rozporządzenia Rady (WE) nr 834/2007 w odniesieniu do ustaleń dotyczących przywozu produktów ekologicznych z krajów trzecich.

Art. 4 rozporządzenia 834/2007.

Art. 5 rozporządzenia 834/2007.

Art. 9 rozporządzenia 834/2007.

Art. 10 rozporzadzenia 834/2007.

Art. 12 oraz 14 rozporządzenia 834/2007. Szerzej na temat prawnych wymogów produkcji ekologicznej zob. K. Leśkiewicz, System jakości produktów rolnictwa ekologicznego aspekty prawne, Poznań 2011, passim.

Zob. art. 23 ust. 1 rozporządzenia 834/2007. 
widzenia (przy opisie handlowym) wyłącznie wtedy, gdy żywność przetworzona została wytworzona zgodnie $\mathrm{z}$ wymogami określonymi dla tego rodzaju żywności, o ile w żywności tej co najmniej 95\% masy składników pochodzenia rolniczego stanowią składniki ekologiczne. ${ }^{36}$ Ponadto, dopuszczone zostało użycie określeń odnoszących się do ekologicznej metody produkcji wyłącznie w wykazie składników (znajdującym się poza głównym polem widzenia, a w przypadku produktów myślistwa lub rybołówstwa także w wykazie składników znajdującym się w głównym polu widzenia), przy czym musi być ono powiązane ze składnikiem ekologicznym i w takim przypadku konieczne jest podanie procentowego udziału składników ekologicznych względem całkowitej ilości składników pochodzenia rolniczego. ${ }^{37}$

Zaznaczyć należy, że samo rozpoczęcie stosowania metod produkcji ekologicznej nie uprawnia do stosowania określeń odnoszących się do ekologicznych metod produkcji. Określenia takie mogą być stosowane dopiero po upływie okresu konwersji, tj. okresu, w trakcie którego następuje przejście z rolnictwa nieekologicznego na rolnictwo ekologiczne, podczas którego stosowane są przepisy dotyczące produkcji ekologicznej. ${ }^{38}$ Okres konwersji jest uzależniony od rodzaju produkcji prowadzonej $\mathrm{w}$ gospodarstwie. Przy produkcji roślinnej wynosi on co najmniej 2 lata przed wysiewem, w przypadku roślin wieloletnich 3 lata przed zbiorem, a dla pasz 2 lata przed zbiorem. ${ }^{39}$ Przy produkcji zwierzęcej, jeśli zwierzęta nieekologiczne są włączane do produkcji, okres karencji wynosi od 6 miesięcy do 12 miesięcy, zależnie od rodzaju zwierzęcia. ${ }^{40}$ Okres konwersji rozpoczyna się najwcześniej z chwilą poinformowania przez podmiot gospodarczy właściwych organów o prowadzonej działalności oraz włączenia gospodarstwa $\mathrm{w}$ system kontroli. ${ }^{41} \mathrm{~W}$ przypadku zwierząt i produktów zwierzęcych wytwarzanych podczas okresu konwersji, niedopuszczalne jest stosowanie jakichkolwiek odniesień do ekologicznych metod produkcji w oznakowaniu i reklamie produktów. ${ }^{42}$ Natomiast produkty pochodzenia roślinnego w okresie konwersji mogą być opatrzone oznaczeniem: ,produkt w trakcie konwersji na rolnictwo ekologiczne". ${ }^{43}$

Stosując określenia odnoszące się do ekologicznej metody produkcji konieczne jest zamieszczenie na etykiecie numeru identyfikacyjnego organu kontrolnego lub jednostki certyfikującej, którym podlega podmiot gospodarczy, który dokonał ostatniej czynności produkcyjnej lub przygotowawczej, a ponadto w odniesieniu do żywności paczkowanej na opakowaniu umieszcza się wspólnotowe logo. ${ }^{44} \mathrm{~W}$ tym

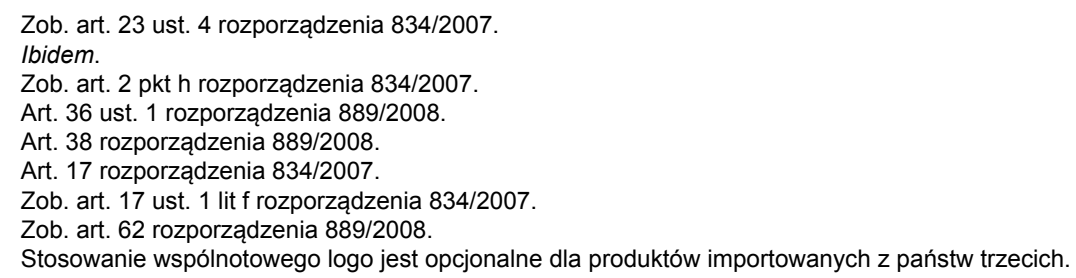


samym polu widzenia co logo umieszcza się oznaczenie miejsca, w którym wyprodukowano nieprzetworzone produkty rolnicze, z których wytworzono końcowy produkt. $^{45}$

Żywność ekologiczna wyróżnia się spośród pozostałych rodzajów żywności poprzez swoje oznakowanie, odnoszące się do ekologicznych metod produkcji. Za żywność ekologiczną w świetle unijnej regulacji uznać zatem można żywność, która w sposób zgodny z przepisami opatrzona została informacją o zastosowaniu ekologicznych metod produkcji lub jakimkolwiek określeniem odwołującym się do tych metod (np. ekologiczny, eko, bio). Oznakowanie takie może być jednak stosowane wyłącznie w odniesieniu do produktów wytworzonych zgodnie z wymogami wynikającymi z przepisów rozporządzenia 834/2007 oraz aktów wykonawczych do niego przez podmioty, które dokonały zgłoszenia rozpoczęcia produkcji z wykorzystaniem metody ekologicznej do upoważnionego podmiotu certyfikującego i które po upływie okresu konwersji uzyskały certyfikat. ${ }^{46}$

\section{4. Żywność ekologiczna w prawie USA}

W wydanej w 1990 r. OFPA zawarte zostały podstawowe definicje i wymogi dotyczące żywności ekologicznej. Regulacja OFPA uzupełniona i uszczegółowiona została w opublikowanym w 2000 r. Narodowym Programie Ekologicznym (NOP). Program ten określa ogólnokrajowe normy dla produkcji i przetwarzania żywności ekologicznej, w tym obejmuje krajowy wykaz substancji dopuszczonych i zakazanych do stosowania w produkcji ekologicznej i przetwarzaniu. Poza tym, ustanowione zostały w nim zasady akredytacji jednostek certyfikujących, wymogi dotyczące etykietowania żywności ekologicznej, a także zasady przywozu produktów rolnictwa ekologicznego z państw trzecich, w których stosowane są równoważne wymogi dotyczące wytwarzania żywności ekologicznej. Zarówno w OFPA, jak i w NOP zdefiniowane zostało szereg pojęć. W OFPA zawarto m.in. definicje takich pojęć, jak: produkt rolny (agricultural product), certyfikowane gospodarstwo ekologiczne (certified organic farm), plan ekologiczny (organic plan), wyprodukowany ekologicznie (organically produced), a w NOP m.in.: ekologiczny (organic), produkcja ekologiczna (organic production).

Oznaczenie to przyjmuje odpowiednio jedną z następujących form: „rolnictwo UE”, gdy surowiec rolniczy wyprodukowano w UE, „rolnictwo spoza UE”, gdy surowiec rolniczy wyprodukowano w krajach trzecich, „rolnictwo UE/ spoza UE”, gdy część surowców wyprodukowano w Unii, a część w kraju trzecim. Oznaczenie „UE” lub „spoza UE” może być zastąpione lub uzupełnione nazwą kraju, jeśli wszystkie surowce, z których wytworzono produkt, wyprodukowano w tym kraju. Zob. art. 24 rozporządzenia 834/2007. uregulowane w rozporządzeniu (WE) nr 178/2002 Parlamentu Europejskiego i Rady z dnia 28 stycznia 2002 r. ustanawiającym ogólne zasady i wymagania prawa żywnościowego, powołującym Europejski Urząd ds. Bezpieczeństwa Żywności oraz ustanawiającym procedury w zakresie bezpieczeństwa żywności (Dz.Urz. WE L 31 $z$ dnia 1 lutego 2002 r., s. 1, ze zm.). Jest to o tyle istotne, że regulacja dotyczące ekologicznych metod produkcji ze względu na to, że dotyczy żywności, objęta jest zakresem prawa żywnościowego. 
Podobnie jak w regulacji unijnej, w prawie amerykańskim definicja żywności ekologicznej nie została wprowadzona, a dla ustalenia znaczenia tego pojęcia wykorzystać można kilka pozostałych definicji. Przede wszystkim zgodnie z OFPA „wyprodukowany ekologicznie” (organically produced) oznacza produkt rolny wytworzony i przetwarzany zgodnie z OFPA. Z kolei zgodnie z NOP, ekologiczny (organic) oznacza oznaczenie stosowane na etykiecie odnoszące się do produktów rolnych wytworzonych zgodnie z tą regulacją ${ }^{47}$ Termin produkcja ekologiczna (organic production) oznacza natomiast system produkcyjny prowadzony zgodnie z NOP, dostosowany do warunków panujących w danym miejscu produkcji, oparty na integracji kulturowej oraz praktykach biologicznych i mechanicznych sprzyjających odnawianiu zasobów naturalnych, promowaniu równowagi ekologicznej i ochronie bioróżnorodności. ${ }^{48}$

$\mathrm{W}$ procesie tworzenia regulacji dotyczącej ekologicznych metod produkcji, jedną z bardziej spornych kwestii była kwestia możliwości stosowania przy produkcji żywności ekologicznej sztucznych substancji chemicznych, a przede wszystkim organizmów genetycznie zmodyfikowanych, napromieniowania i osadów ściekowych. W przedłożonym przez USDA w 1997 r. do konsultacji społecznych projekcie NOP dopuszczono możliwość wykorzystania sztucznych substancji chemicznych, inżynierii genetycznej oraz napromieniowania przy produkcji ekologicznej, co wywołało ogromne oburzenie wśród producentów stosujących ekologiczne metody produkcji. ${ }^{49}$ Ostatecznie w NOP wprowadzono zasadę, zgodnie z którą oznakowania produktu jako „100\% ekologiczny” (100 percent organic), ekologiczny (organic) lub „wytworzony z ekologicznych” ("made with organic") jest dopuszczalne wyłącznie wówczas, gdy przy produkcji, przetwarzaniu i obróbce nie są wykorzystywane: (a) syntetyczne substancje chemiczne i składniki z wyłączeniem substancji wyraźnie dopuszczonych, (b) określone w NOP niesyntetyczne substancje, (c) substancje pochodzenia nierolniczego wykorzystywane przy przetwarzaniu żywności, z wyłączeniem wyraźnie dopuszczonych w NOP, (d) nieekologiczne substancje pochodzenia rolniczego, z wyłączeniem wskazanych w NOP substancji, (e) metody wykorzystywane dla genetycznej modyfikacji organizmów lub wpływające na wzrost i rozwój w sposób, w jaki nie jest to możliwe naturalnie, (f) napromieniowywanie jonizujące, $(\mathrm{g})$ osady ściekowe. ${ }^{50}$

Zgodnie z OFPA produkt może być sprzedawany lub oznaczony jako ekologiczny wyłącznie, gdy jest wytworzony bez użycia syntetycznych substancji chemicznych (z wyłączeniem substancji dopuszczonych do produkcji ekologicznej, zawartych na „Krajowej liście substancji i metod zabronionych - „National List of approved and prohibited substances", wydanej przez Sekretarza Stanu do spraw

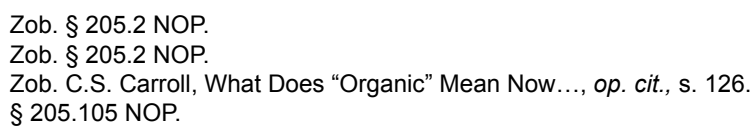


Rolnictwa na podstawie OFPA), upłynął co najmniej trzyletni okres, w trakcie którego na obszarze, na którym prowadzona jest produkcja ekologiczna nie były używane syntetyczne substancje chemiczne oraz jest wytwarzany i przetwarzany, pakowany i sprzedawany zgodnie $\mathrm{z}$ planem ekologicznym przygotowanym przez producenta i zatwierdzonym przez podmiot certyfikujący (certifying agent). ${ }^{51}$

Żywność wytworzona zgodnie z OFPA może być oznaczona jako ekologiczna (organic), a ponadto na etykiecie może być zamieszczona informacja, że produkt jest zgodny z normami ustanowionymi przez Departament Rolnictwa lub opatrzony specjalną pieczęcią (znak, logo) Departamentu Rolnictwa (Department of Agriculture seal).$^{52}$ Zabronione jest użycie określeń wskazujących w sposób bezpośredni lub pośredni, iż dany produkt jest wytworzony lub przetwarzany z wykorzystaniem metod ekologicznych, w przypadku gdy nie spełnia on wymogów określonych w OFPA. ${ }^{53}$ Przewiduje się jednak kilka odstępstw. W odniesieniu do żywności przetworzonej dopuszczono możliwość użycia określenia „ekologiczna” (organic) na przedniej części etykiety (principal display panel of product), ale bez możliwości użycia znaku Departamentu Rolnictwa (Department of Agriculture seal), w przypadku gdy żywność zawiera co najmniej 50\% składników ekologicznych. Poza tym, w przypadku żywności zawierającej mniej niż 50\% składników ekologicznych dopuszczalne jest użycie słowa „ekologiczny” (organic) przy poszczególnych składnikach, w części etykiety zawierającej wykaz składników. ${ }^{54}$ Ponadto, możliwe jest używanie określeń odwołujących się do produkcji ekologicznej bez spełnienia wymogów przewidzianych w OFPA przez „,małych rolników” (small farmers), tj. osób, które sprzedają produkty rolne o wartości nie przekraczającej 5 tys. USD w ciągu roku. ${ }^{55} \mathrm{~W}$ tym przypadku nie ma obowiązku przygotowania planu ekologicznego oraz poddania się procesowi certyfikacji, jednak produkcja i przetwarzanie muszą być prowadzone zgodnie z wymogami właściwymi dla produkcji ekologicznej (m.in. wymagania dotyczące gruntu, żyzności gruntów, nawozów, praktyk rolniczych, chowu zwierząt, sposobów przetwarzania). ${ }^{56} \mathrm{~W}$ NOP doprecyzowano zasady znakowania, wprowadzając kilka kategorii żywności znakowanej jako ekologiczna, tj. (1) $100 \%$ ekologiczna (100 percent organic) dopuszczalne, gdy produkt zawiera $100 \%$ składników wyprodukowanych ekologicznie (organically produced), (2) ekologiczna (organic), dopuszczalne, gdy produkt zawiera nie mniej niż 95\% składników wyprodukowanych ekologicznie, (3) wyprodukowane z ekologicznego, z podaniem składników lub kategorii żywności (made with organic, specified ingredients or food group(s) dopuszczalne, gdy produkt zawiera nie mniej niż $70 \%$ składników wyprodukowanych ekologicznie, (4) produkty z mniej niż 70\% składników ekolo-

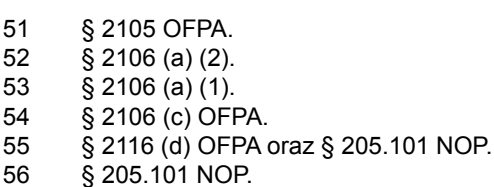


gicznych - Products with less than 70 percent organically produced ingredients) ${ }^{57}$ Oznaczenie ,100\% ekologiczne” i „ekologiczny” może być zamieszczone na głównym polu widzenia, może modyfikować nazwę produktu i może być łączone z użyciem znaku Departamentu Rolnictwa (Department of Agriculture seal) oraz znaku (logo) jednostki certyfikującej wytwarzanie produktu końcowego. ${ }^{58} \mathrm{~W}$ przypadku tych produktów konieczne jest też podanie, poniżej nazwy producenta, nazwy jednostki certyfikującej i jej dane adresowe. ${ }^{59}$ Na przedniej części etykiety może być też zamieszczone oznakowanie „wyprodukowane z ekologicznego”, przy czym w tym przypadku konieczne jest wymienienie składników lub kategorii żywności (np. owoce, mięso, oleje, nasiona) oraz podanie procentowego udziału składników wyprodukowanych ekologicznie (czcionką nie mniejszą niż $1 / 2$ największej czcionki użytej w głównym polu widzenia), a ponadto można wskazać logo jednostki certyfikującej. ${ }^{60} \mathrm{~W}$ przypadku tych produktów, w wykazie składników należy wskazać, które ze składników są ekologiczne oraz poniżej nazwy producenta należy podać nazwę jednostki certyfikującej i jej dane adresowe. ${ }^{61}$ Wieloskładnikowe produkty z zawartością mniej niż 70\% wyprodukowanych ekologicznie składników mogą być opatrzone jedynie znakiem ,ekologiczny” przy danym składniku w wykazie składników, nie jest natomiast dopuszczalne użycie znaku (logo) jednostki certyfikującej. ${ }^{62}$

Wszelkie czynności związane z wytwarzaniem lub przetwarzaniem żywności ekologicznej muszą być podejmowane przez certyfikowane podmioty. ${ }^{63}$ Zamieszczenie oznakowania jest dopuszczalne wyłącznie na produktach, które zostały wyprodukowane metodami ekologicznymi, stanowi ono raczej potwierdzenie zastosowania specjalnej metody produkcji, przetwarzania i obróbki produktu, a nie potwierdzenie jakości. ${ }^{64}$ Przyjęta w USA regulacja prawna dotycząca żywności ekologicznej skupiona jest zatem, podobnie jak regulacja unijna, na procesie wytwarzania, a nie na produkcie. $\mathrm{Z}$ punktu widzenia ochrony konsumenta negatywnie ocenić należy to, iż obok regulowanego oznakowania „ekologiczny” (organic), w USA produkty mogą być znakowane takimi określeniami, jak ,naturalny”, „dziki” lub „,bez pozostałości” (natural, wild, residual free). ${ }^{65} \mathrm{~W}$ tym zakresie regulacja unijna lepiej chroni interes konsumenta, zabronione jest bowiem używanie jakichkolwiek określeń odnoszących się do ekologicznej metody produkcji. ${ }^{66}$

Rozwiązanie przyjęte w USA powoduje, że podobnie jak w przypadku regulacji unijnej, elementem wyróżniającym żywność ekologiczną jest jej oznakowanie jako

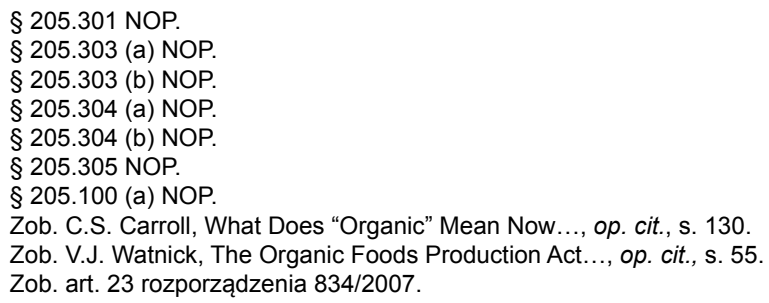


„ekologiczna”, przy czym stosowanie tego oznakowania dopuszczalne jest wyłącznie przez certyfikowane podmioty stosujące ekologiczne metody produkcji zgodne z regulacją OFPA i NOP.

\section{Wpływ wsparcia publicznego na żywność ekologiczną}

Zarówno w UE, jak i w USA przewiduje się wsparcie publiczne dla produkcji ekologicznej. W USA od 2002 r. ze środków publicznych finansowane są różnego rodzaju działania przyczyniające się do rozwoju produkcji ekologicznej, m.in. finansowane są badania związane $\mathrm{z}$ produkcją ekologiczną (Organic agriculture research and extension initiative) oraz refundowane koszty związane z produkcją ekologiczną (Organic Certification Cost Share Programs). Już w 2002 r. przewidywano pomoc publiczną w postaci zwrotu do $75 \%$ kosztów związanych z uzyskaniem certyfikacji, ale nie więcej niż 500 USD) ${ }^{67}$ Program współfinansowania kosztów certyfikacji ekologicznej (Organic Certification Cost Share Programs OCCSP) przewidziany został także w najnowszej ustawie o rolnictwie z 7 lutego $2014 \mathrm{r}^{68}$ (Agricultural Act of 2014 zwany też Farm Bill 2014 ${ }^{69}$ ). Na program ten składają się dwa podprogramy, Krajowy Program Współfinansowania Kosztów Certyfikacji Ekologicznej (National Organic Certification Cost Share Program - NOCCSP) oraz Program Zarządzania Wsparciem Wspólfinansowania Kosztów Certyfikacji Ekologicznej (Agricultural Management Assistance Organic Certification Cost Share Program - AMA).$^{70} \mathrm{~W}$ ramach NOCCSP przewiduje się dofinansowanie dla rolników i przedsiębiorców przetwarzających żywność ekologiczną w kwocie 75\% kosztów kwalifikowanych poniesionych w związku z certyfikacją, jednak nie przekraczającą 750 USD rocznie na każdy z czterech zakresów (tj. rośliny uprawne, zwierzęta, dzikie rośliny, przetwórstwo). Maksymalne wsparcie dla jednego podmiotu wynosi zatem 3 tys. USD i ma miejsce w przypadku, gdy podmiot prowadzi produkcję ekologiczną we wszystkich 4 obszarach, a wysokość kosztów kwalifikowanych przekracza 4 tys. USD (75\%). Drugi z programów, tj. AMA jest realizowany tylko w 16 stanach i w ramach tego programu m.in. finansowane są wydatki związane z konwersją na produkcję ekologiczną. Rolnik może otrzymać na ten cel nie więcej niż 50 tys. USD. ${ }^{71}$

W Unii Europejskiej wsparcie dla rolników prowadzących działalność w zakresie rolnictwa ekologicznego było przewidziane już w Programie Rozwoju Obsza-

Zob. http://www.ams.usda.gov/AMSv1.0/getfile?dDocName=STELPRDC5100865

Dostępny na: http://www.gpo.gov/fdsys/pkg/BILLS-113hr2642enr/pdf/BILLS-113hr2642enr.pdf

Zob. http://www.ers.usda.gov/agricultural-act-of-2014-highlights-and-implications/organic-agriculture.aspx Zob. http://www.ams.usda.gov/AMSv1.0/NOPFactSheets

Informacje o programie dostępne są na: http://www.nrcs.usda.gov/wps/portal/nrcs/detail/national/programs/financial/ama/?cid=stelprdb1242818 
rów Wiejskich na lata 2004-2006 ${ }^{72}$ oraz na lata $2007-2013 .{ }^{73}$ Wsparcie bezpośrednio dla rolnictwa ekologicznego przewidziane zostało w rozporządzeniu nr 1305/2013, ${ }^{74}$ gdzie pośród wielu działań przewidziane zostało działanie „Rolnictwo ekologiczne” (art. 29), w ramach którego przewiduje się wsparcie na hektar użytków rolnych rolnikom lub grupom rolników, którzy dobrowolnie podejmują się konwersji lub utrzymania praktyk i metod rolnictwa ekologicznego określonych w rozporządzeniu nr 834/2007 i którzy są rolnikami aktywnymi zawodowo w rozumieniu art. 9 rozporządzenia nr 1307/2013. Działanie to uwzględnione zostało w Programie Rozwoju Obszarów Wiejskich na lata 2014-2020, ${ }^{75}$ gdzie przewiduje się dwa poddziałania „Płatności w okresie konwersji na rolnictwo ekologiczne” oraz „Płatności w celu utrzymania rolnictwa ekologicznego".

Warto odnotować, że w polskim prawie krajowym, szczegółowe warunki i tryb przyznawania, wypłaty oraz zwrotu pomocy finansowej w ramach działania „Rolnictwo ekologiczne" określone zostały w Rozporządzeniu Ministra Rolnictwa i Rozwoju Wsi z dnia 13 marca 2015 r. w sprawie szczegółowych warunków i trybu przyznawania pomocy finansowej w ramach działania „Rolnictwo ekologiczne” objętego Programem Rozwoju Obszarów Wiejskich na lata 2014-2020. ${ }^{76}$ Przewiduje się w nim kilkanaście różnych pakietów pomocy (uprawy rolnicze, warzywne, zielarskie, sadownicze oraz paszowe w okresie konwersji oraz po okresie konwersji, a także trwałe użytki zielone w okresie konwersji i po okresie konwersji). Płatność jest przyznawana rolnikom spełniającym określone w tym rozporządzeniu wymagania, m.in. prowadzenie produkcji zgodnie $\mathrm{z}$ wymaganiami rozporządzenia nr 834/2007 oraz wytwarzanie produktów rolnictwa ekologicznego (obowiązku wytworzenia takich produktów nie ma jedynie w pakiecie ,trwałe użytki zielone”). ${ }^{77}$ Wprowadzenie obowiązku wytworzenia produktów ekologicznych stanowi wzmocnienie tzw. nurtu podstawowego regulacji prawnej produkcji metodami ekologicznymi. ${ }^{78} \mathrm{O}$ ile bowiem już samo prowadzenie produkcji metodami ekologicznymi

Było ono realizowane w ramach Pakietu 2: „Rolnictwo ekologiczne” w ramach Działania 4: „Wspieranie przedsięwzięć rolnośrodowiskowych i poprawy dobrostanu zwierząt”. Realizacja pakietu polegała na podejmowaniu przez rolnika działań, które miały przyczynić się do upowszechnienia systemów produkcji rolniczej, zgodnych z wymogami ochrony środowiska oraz ochrony zasobów genetycznych zwierząt gospodarskich.

73 Były uruchomione trzy działania, w ramach których producenci ekologiczni kwalifikowali się do wsparcia: „Program rolnośrodowiskowy”, „Uczestnictwo rolników w systemach jakości żywności” oraz „Działania informacyjne i promocyjne".

74 Rozporządzenie Parlamentu Europejskiego i Rady (UE) nr 1305/2013 z dnia 17 grudnia 2013 r. w sprawie wsparcia rozwoju obszarów wiejskich przez Europejski Fundusz Rolny na rzecz Rozwoju Obszarów Wiejskich (EFRROW) (Dz.Urz. UE L 347 z dnia 20 grudnia 2013 r., s. 487). Informacja o zatwierdzeniu PROW przez Komisję oraz miejscu jego podania do informacji publicznej zawarta jest w Komunikacie Ministra Rolnictwa i Rozwoju Wsi z dnia 21 maja 2015 r. o zatwierdzeniu Programu Rozwoju Obszarów Wiejskich na lata 2014-2020 oraz o adresie strony internetowej na której został on zamieszczony (M.P. poz. 541). PROW udostępniony jest pod adresem: http://www.minrol.gov.pl/Wsparcie-rolnictwa-i-rybolowstwa/PROW-2014-2020.

$76 \quad$ Dz.U. z 2015 r. poz. 370.

77 Zob. § 9 rozporządzenia w sprawie szczegółowych warunków i trybu przyznawania pomocy finansowej w ramach działania „Rolnictwo ekologiczne”.

78 Zob. S. Prutis, Regulacje prawne produkcji ekologicznej..., op. cit., s. 42. 
przyczynia się do ochrony środowiska (grunty wyłączone są z intensywnej produkcji rolnej), o tyle wymóg wytworzenia produktów sprzyja zwiększeniu konkurencji na rynku żywności ekologicznej, co stanowi element ochrony interesów ekonomicznych konsumenta. Niestety to pozytywne oddziaływanie na rynek osłabione jest tym, że nie przewiduje się pomocy dla produkcji żywności ekologicznej pochodzenia zwierzęcego.

Zaznaczyć przy tym należy, że w polskiej regulacji dla potrzeb przyznania pomocy w ramach działania rolnictwo ekologiczne pojęcie produktów rolnictwa ekologicznego rozumiane jest w sposób szerszy od zaproponowanego w niniejszym artykule. Co prawda, rozporządzenie w sprawie szczegółowych warunków i trybu przyznawania pomocy finansowej w ramach działania „Rolnictwo ekologiczne” odsyła do ustawy o rolnictwie ekologicznym, ${ }^{79}$ zgodnie z którą przez produkty rolnictwa ekologicznego rozumie się produkty uznane za ekologiczne w rozumieniu art. 2 lit. c rozporządzenia nr 834/2007, ${ }^{80}$ jednak przewidziany w tym rozporządzeniu obowiązek wytworzenia ,,produktów rolnictwa ekologicznego" dotyczy produktów wytworzonych nie tylko po okresie konwersji, ale także w okresie konwersji, które nie mogą być oznakowane jako ekologiczne, ale jedynie jako ,produkt w trakcie konwersji na rolnictwo ekologiczne". Takie rozwiązanie oznacza, że w rozumieniu tego rozporządzenia żywnością ekologiczną są zarówno produkty, które zgodnie z rozporządzeniem nr 834/2007 mogą być oznakowane jako „ekologiczne”, jak też produkty, które jeszcze nie mogą być oznakowane jako ekologiczne.

Wsparcie dla produkcji metodami ekologicznymi jest też przewidziane w ramach objętego rozporządzeniem nr 1305/2013 działania „Systemy jakości produktów rolnych i środków spożywczych" (art. 16), obejmującego dwa poddziałania: wsparcie dla nowych uczestników systemów jakości (art. 16 ust. 1 rozporządzenia nr 1305/2013) oraz wsparcie na przeprowadzenie działań informacyjnych i promocyjnych przez grupy producentów rolnych (art. 16 ust. 2 rozporządzenia nr 1305/2013). Obydwa te poddziałania ujęte zostały w PROW na lata 2014-2020. Prowadzenie produkcji metodami ekologicznymi jest też jednym z kryteriów branych pod uwagę przy ocenie i selekcji wniosków o pomoc w ramach innych działań. ${ }^{81}$ Poza pomocą w ramach PROW, ze względu na udowodnione korzyści dla środowiska wynikające z systemów rolnictwa ekologicznego, rolnicy prowadzący gospodarstwa ekologiczne są uprawnieni do płatności z tytułu praktyk rolniczych korzystnych dla klimatu i środowiska (tzw. płatności na zazielenienie), przewidzianych w rozporządze-

Ustawa z dnia 25 czerwca 2009 r. o rolnictwie ekologicznym (Dz.U. Nr 116, poz. 975 oraz z 2015 r. poz. 55 i 349 ). Tekst jedn. produkty, które zostały wytworzone zgodnie z rozporządzeniem nr 834/2007, po okresie konwersji, przez podmiot, który uzyskał certyfikat i które zostały oznakowane jako ekologiczne.

Prowadzenie produkcji metodami ekologicznymi uwzględnia się jako kryterium selekcji wniosków w PROW na lata 2014-2020 w poddziałaniach: Pomoc na inwestycje w przetwórstwo/marketing i rozwój produktów rolnych (Przetwórstwo i marketing produktów rolnych), s. 180; pomoc na wsparcie inwestycji w gospodarstwach rolnych, s. 193; Pomoc na rozpoczęcie działalności gospodarczej na rzecz rozwoju małych gospodarstw (Restrukturyzacja małych gospodarstw), s. 234. 
niu nr 1307/2008 ${ }^{82}$ bez konieczności spełniania dodatkowych wymogów, innych niż przewidziane w rozporządzeniu nr 834/2007 (pkt 38 preambuły oraz art. 43 ust. 11 rozporządzenia nr 1307/2008). W tym przypadku kluczowe znaczenie ma funkcja środowiskowa produkcji ekologicznej, a nie wytworzenie żywności ekologicznej.

\section{Mechanizm uznawania równorzędności wymogów prawa EU i USA dotyczących żywności ekologicznej}

W dniu 1 czerwca 2012 roku weszło w życie porozumienie pomiędzy Unią Europejską a Stanami Zjednoczonymi o wzajemnym uznawaniu oznakowań żywności ekologicznej (organic equivalency arrangement). Zgodnie z umową Stany Zjednoczone uznają unijną regulację dotyczącą żywności ekologicznej jako równorzędną w stosunku do Narodowego Programu Ekologicznego USA (National Organic Program, NOP) i zezwalają na sprzedaż produktów spełniających wymagania europejskiego programu i posiadających certyfikat UE jako „organic” w USA. Z drugiej strony, na podstawie kontroli zasad produkcji i środków kontroli funkcjonujących w USA oraz uzyskanych od władz USA informacji Komisja uznała, że przepisy regulujące produkcję i kontrolę ekologicznych produktów rolnych w USA są równoważne z przepisami ustanowionymi w rozporządzeniu nr 834/2007. ${ }^{83}$ Stany Zjednoczone włączone zostały do wykazu uznanych państw trzecich ustanowionego W załączniku III do rozporządzenia nr 1235/2008. ${ }^{84} \mathrm{~W}$ wykazie tym określone zostały kategorie produktów, ${ }^{85}$ pochodzenie,${ }^{86}$ normy produkcyjne,${ }^{87}$ właściwy organ,${ }^{88}$ jednostki certyfikujące i wystawiające świadectwo ${ }^{89}$ oraz termin ważności wpisu. ${ }^{90}$

Rozporządzenie Parlamentu Europejskiego i Rady (UE) nr 1307/2013 ustanawiające przepisy dotyczące płatności bezpośrednich dla rolników na podstawie systemów wsparcia w ramach Wspólnej Polityki Rolnej i uchylające rozporządzenia Rady (WE) nr 637/2008 i (WE) nr 73/2009 (Dz.Urz. UE L 347 z dnia 20 grudnia 2013 r., s. 608). Zob. pkt. 4 preambuły do rozporządzenia wykonawczego Komisji nr 126/2012 z 14 lutego 2012 zmieniającego rozporządzenie (WE) nr 889/2008 w odniesieniu do certyfikatów oraz zmieniające rozporządzenie (WE) nr 1235/2008 w odniesieniu do ustaleń dotyczących przywozu produktów ekologicznych ze Stanów Zjednoczonych Ameryki (Dz.Urz. UE L 41 z dnia 15 lutego 2012 r., s. 5).

84 Zmiana dokonana została przez rozporządzenie wykonawcze Komisji nr 126/2012 z 14 lutego 2012 zmieniające rozporządzenie (WE) nr 889/2008 w odniesieniu do certyfikatów oraz zmieniające rozporządzenie (WE) nr 1235/2008 w odniesieniu do ustaleń dotyczących przywozu produktów ekologicznych ze Stanów Zjednoczonych Ameryki (Dz.Urz. UE L 41 z dnia 15 lutego 2012 r., s. 5).

Wymienione zostały następujące kategorie żywności: nieprzetworzone produkty roślinne, żywe zwierzęta lub nieprzetworzone produkty pochodzenia zwierzęcego, przetworzone produkty rolne przeznaczone do spożycia, przetworzone produkty rolne przeznaczone na paszę, wegetatywny materiał rozmnożeniowy i nasiona uprawne. Dodane zostało zastrzeżenie, że w przypadku jabłek i gruszek - przywóz podlega obowiązkowi okazania specjalnego certyfikatu wydanego przez właściwą jednostkę certyfikującą lub właściwy organ kontrolny, potwierdzającego, iż podczas procesu produkcji nie stosowano antybiotyków (takich jak tetracyklina i streptomycyna) w celu zwalczania zarazy ogniowej. Wytworzone w USA lub przywiezione do USA i przetworzone i znakowane w USA zgodnie z obowiązującymi w USA przepisami.

87 Wskazane zostały OFPA oraz NOP.

88 Wskazane zostały: United States Department of Agriculture (USDA), Agricultural Marketing Service (AMS), www. usda.gov

89 Ponad 50 podmiotów, w wykazie podana jest nazwa oraz adres strony internetowej.

90 Termin ważności wpisu ustalony został na 30 czerwca 2015 r, jednak ważność tego wpisu została przedłużona na czas nieokreślony na mocy rozporządzenia wykonawczego Komisji nr 2015/931 z dnia 17 czerwca 2015 r. 
W konsekwencji produkty wytworzone zgodnie z wymaganiami dotyczącymi ekologicznej metody produkcji i oznaczone jako ekologiczne w USA i UE uznawane są za ekwiwalentne na obydwu rynkach z dwoma wyjątkami. Rośliny ekologiczne wytworzone w USA, przy uprawie których użyto antybiotyki, nie mogą być wprowadzane do UE, a żywność pochodzenia zwierzęcego wytworzona w UE ze zwierząt, które były leczone antybiotykami nie może być wprowadzana na rynek USA. Żywność ekologiczna jest wysyłana wraz ze świadectwem kontroli wystawionym przez uznaną jednostkę certyfikującą. Oznacza to, że do USA można wprowadzać produkty z UE oznakowane logiem UE, natomiast do UE można wprowadzać produkty z USA oznaczone logiem USDA. Ponadto, produkty wytwarzane w USA można znakować logiem unijnym, a wytwarzane w UE logiem USDA. Pewne wątpliwości dotyczą dopuszczonej w prawie USA kategorii żywności ,wytworzone z ekologicznego" (organically produced). Taka kategoria żywności ekologicznej nie występuje w prawie unijnym, a biorąc pod uwagę, że tego rodzaju żywność przetworzona zawiera poniżej 95\% (od 70-95\%) składników wytworzonych metodą ekologiczną, zgodnie z prawem unijnym niedopuszczalne jest stosowanie w oznakowaniu tego rodzaju żywności oznaczeń odwołujących się do ekologicznej metody produkcji. Biorąc pod uwagę cele prawa żywnościowego, a w szczególności ochronę interesów ekonomicznych konsumentów, uznać należy, że tego rodzaju żywność nie może być wprowadzana na rynek unijny z etykietami dopuszczonymi w prawie USA (możliwe jest wprowadzanie tego rodzaju produktów jedynie z informacją o ekologicznym pochodzeniu poszczególnych składników w wykazie składników).

\section{Zakończenie}

Żywność ekologiczna stanowi kategorię żywności wyróżniającą się szczególną jakością ze względu na zastosowanie ekologicznej metody produkcji. Popyt na produkty ekologiczne powoduje ciągły rozwój rynku żywności ekologicznej w krajach wysoko rozwiniętych. Zarówno w UE, jak i w USA wydana została bardzo obszerna regulacja dotycząca produkcji i dystrybucji produktów rolnictwa ekologicznego, jednak samo pojęcie „żywność ekologiczna” nie zostało zdefiniowane. Na podstawie obydwu regulacji za żywność ekologiczną uznać należy te produkty żywnościowe, które oznakowane zostały w sposób wskazujący na wytworzenie ich z wykorzystaniem ekologicznych metod produkcji. Zamieszczenie takiego znaku dopuszczalne jest jednak wyłącznie na produktach wytworzonych zgodnie z przepisami określającymi wymogi dotyczące produkcji ekologicznej odpowiednio w UE i USA. Oznaczenie takie może być stosowane wyłącznie przez certyfikowane pod-

w sprawie zmiany i sprostowania rozporządzenia (WE) nr 1235/2008 ustanawiającego szczegółowe zasady wykonania rozporządzenia Rady (WE) nr 834/2007 w odniesieniu do ustaleń dotyczących przywozu produktów ekologicznych z krajów trzecich (Dz.Urz. UE L 151 z dnia 18 czerwca 2015 r., s. 1). 
mioty, po upływie okresu konwersji z produkcji konwencjonalnej na ekologiczną. Systemy produkcji ekologicznej Unii Europejskiej i USA zostały uznane za wzajemnie równoważne, co oznacza, że żywność ekologiczna wytworzona i oznakowana w USA i UE może być dystrybuowana jako ekologiczna, bez żadnych dodatkowych wymogów odpowiednio w UE i USA. Pomimo uznania równoważności systemów produkcji ekologicznej, warto zwrócić uwagę na pewne różnice w podejściu do regulacji żywności ekologicznej.

Przede wszystkim, regulacja amerykańska jest bardziej elastyczna i w sposób zdecydowanie silniejszy nastawiona jest na ochronę interesów przedsiębiorców i rolników (a nie wyłącznie ochronę interesów konsumentów, jak ma to miejsce w regulacji unijnej). W związku z tym, wprowadzone zostały pewne odstępstwa dotyczące znakowania żywności określeniami odwołującymi się do ekologicznych metod produkcji. Dopuszczono możliwość używania oznaczeń odnoszących się do produkcji ekologicznej przez drobnych rolników (tj. osoby, które sprzedają produkty rolne o wartości nie przekraczającej 5 tys. USD w ciągu roku) bez konieczności poddawania się przez nich procesowi certyfikacji, co umożliwia rozwijanie produkcji ekologicznej w małych gospodarstwach dla zaspokojenia potrzeb rynku lokalnego. Wprowadzono kategorię żywności ,wyprodukowane z ekologicznego” (made with organic), gdzie informacja odwołująca się do produkcji ekologicznej może być zamieszczana w głównym polu widzenia na środkach spożywczych zawierających nie mniej niż 70\% składników wyprodukowanych ekologicznie, co daje możliwość czerpania korzyści wynikającej z zastosowania oznakowania odwołującego się do produkcji ekologicznej, już w przypadku produktów, które zawierają aż 30\% składników nieekologicznych. Jednocześnie wprowadzono kategorię żywności 100\% ekologiczna (100 percent organic), co pozwala w sposób szczególny wyróżniać produkty w pełni ekologiczne. Rozwiązania te są korzystne przede wszystkim dla przedsiębiorców, którzy mają o wiele większą swobodę niż w przypadku regulacji unijnej, a przez to mogą oni bardziej elastycznie dostosować się do potrzeb rynkowych. W pewnym stopniu amerykańskie rozwiązania są także korzystne dla konsumentów, którzy mogą dokonywać wyboru pomiędzy różnymi kategoriami produktów ekologicznych, stosownie do swoich oczekiwań i możliwości finansowych. Przyznać jednak należy, że istnienie kilku kategorii produktów ekologicznych może powodować niezrozumienie u części konsumentów. W regulacji unijnej zdecydowanie bardziej restrykcyjnie traktowane jest używanie różnego rodzaju określeń, które pośrednio nawiązują do produkcji z wykorzystaniem metod ekologicznych, co zapewnia lepszą ochronę konsumentów.

Cechą odróżniającą europejską i amerykańską regulację jest też to, że wsparcie z funduszy unijnych dla produkcji ekologicznej było przede wszystkim wiązane z samym prowadzeniem produkcji, a nie z wytworzeniem i wprowadzeniem na rynek żywności ekologicznej. W obecnym okresie programowania w regulacji krajo- 
wej w Polsce wprowadzona została w tym zakresie istotna zmiana. Do obowiązków beneficjenta w ramach działania ,produkcja ekologiczna” należy wytworzenie produktów ekologicznych. Rozwiązanie takie sprzyja zwiększeniu produkcji produktów ekologicznych, a przez to korzystnie wpływa na rozwój konkurencji na rynku żywności ekologicznej. Biorąc pod uwagę, że żywność ekologiczna wytwarzana na rynku unijnym konkuruje z żywnością z państw trzecich, w tym z żywnością ekologiczną z USA, zdecydowanie należy opowiedzieć się za wprowadzeniem takich instrumentów wspierania produkcji ekologicznej, które nie tylko będą wpływały na poprawę stanu środowiska, ale które przede wszystkim będą wpływały na rozwój produkcji żywności ekologicznej. 
ORGANIC FOOD IN THE EU AND USA LEGISLATION $\mathrm{EU}$

Key words: organic food, improvement of the environment, competitiveness of

The demand for, characterized by the special quality, organic products causes ongoing development the organic food market in highly developed countries. Both in the EU and the USA has been issued legal acts on the production and distribution of organic products. On the basis of an agreement between the USA and EU systems for organic production are recognized as equivalent to each other, which means that organic food manufactured and labeled in the US and the EU can be distributed as organic, without any additional requirements respectively in the EU and the USA.

In the article authors compared the EU and US regulations concerning organic food, including proposed a definition of organic food that has not been explicitly defined in EU nor USA legislation. Comparison of the two legal systems leads to the conclusion that the concept of organic food is similar in the EU and the USA, however the American regulation is more flexible and much stronger is focused on protecting the interests of entrepreneurs and farmers (and not solely to protection the interests of consumers, as is in the regulation of the EU).

In both systems public aid is applied, however in the EU legislation the main aim of support is the improvement of the environment. The authors conclude that the aim of the public support should be primarily to increase the competitiveness of EU production of organic food.

\section{Bibliografia:}

K.C. Amaditz, The Organic Foods Production Act of 1990 and Its Impending Regulations: A Big Zero for Organic Food?, Food and Drug Law Journal 1997.

C.S. Carroll, What Does "Organic" Mean Now? Chickens and Wild Fish are Undermining the Organic Food Production Act of 1990, „San Joaquin Agricultural Law Review” 2004, 117.

R. Johnson, CRS Report for Congres, Organic Agriculture in the United States: Program and Policy Issues, Congressional Reserch Service, 2008.

D. Komorowska, Ekonomika produkcji ekologicznej w Polsce, „Zeszyty Naukowe Szkoły Głównej Gospodarstwa Wiejskiego: Ekonomika i Organizacja Gospodarki Żywnościowej” 2009, nr 73.

M.A. Król, Koncepcja rolnictwa ekologicznego, [w:] Prawo rolne, Problemy teorii i praktyki, R. Budzinowaki, A. Zieliński (red.), Kluczbork 2002.

K. Leśkiewicz, System jakości produktów rolnictwa ekologicznego aspekty prawne, Poznań 2011.

S. Prutis, Regulacje prawne produkcji ekologicznej w rolnictwie polskim, „Studia Iuridica Agraria” 2013, t. XI. 
D. Stankiewicz, Rolnictwo ekologiczne, Informacja nr 673, Biuro Studiów i Ekspertyz, 1999 r, dostępne na: http://biurose.sejm.gov.pl/teksty/i-673.htm (data dostępu: 12.08.2015 r.).

V.J. Watnick, The Organic Foods Production Act, the Process/Product Distinction, and a Case for More End Product Regulation in the Organic Foods Market, „UCLA Journal of Environmental Law and Policy" 2014, 32(1).

P. Wojciechowski, Gospodarstwo rodzinne jako gospodarstwo ekologiczne w prawie polskim i prawie UE, [w:] Prawne mechanizmy wspierania i ochrony rolnictwa rodzinnego w Polsce i innych państwach Unii Europejskiej, P. Litwiniuk (red.), Warszawa 2015.

M. Zuba, Szanse i bariery w integracji łańcucha żywności ekologicznej w Polsce, „Zeszyty Naukowe Wyższej Szkoły Ekonomii i Informatyki” seria Ekonomia 2012, z. 3. 